\title{
ВОЗМОЖНОСТИ СОТРУДНИЧЕСТВА ИРАНА СО СТРАНАМИ ЦЕНТРАЛЬНОЙ АЗИИ ПОСЛЕ ЯДЕРНОГО СОГЛАШЕНИЯ
}

\begin{abstract}
Аннотация. Предметом исследования являются взаимоотношения Ирана и республик Центральной Азии, а также существующие возможности для расширения их сотрудничества. Крепкие и близкие отношения между Ираном и странами Центральной Азии способствовали укреплению национальной безопасности и экономическому развитию сторон. Тем не менее отношения Ирана с этими странами не достигли приемлемого уровня. Безусловно, в последние два десятилетия Соединенные Штаты являются наиболее важным фактором, определяющим отношения сторон. В статье рассматривается высокий потенциал в рамках многостороннего сотрудничества между сторонами в таких важных областях, как: развитие транспортной системы и обмен товарами; транспортировка нефти и газа на территории Ирана; российско-иранского сотрудничество в области транспортировки нефти и газа в странах Центральной и Юго-Восточной Азии; и борьба с терроризмом и исламским радикализмом в регионе. Методологической основой исследования являются исторический и сравнительно-политический подходы, предложения по новым взглядам на »Региональная Интеграция в Центральной Азии. Автор приходит к выводу о том, что ядерное соглашение Ирана с крупными державами, отмена санкций и уменьшение политического и экономического давления США на Иран приведут к благоприятному и взаимодополняющему сотрудничеству между Ираном и странами Центральной Азии. Результатом этого взаимодействия, с расширением основных общих интересов, может стать создание торгово-экономического союза в регионе.

Ключевые слова: Иран, Центральная Азия, США, Россия, ядерное соглашение, санкция, Ближний Восток, терроризм, экономическое сотрудничество, транзит товаров.

Review: This article examines the relations between Iran and Central Asian states and the existing possibilities to extend their cooperation. Strong and close relations between Iran and Central Asian countries have improved national security and economic development of the parties. Nevertheless, Iran's relations with these countries have not reached an acceptable level. Certainly, in the past two decades, the United States have been the most important factor determining the relations between the parties. The article considers the high potential for bilateral and multilateral cooperation between the parties in such important areas as development of transport system and exchange of goods, oil and gas transportation and the struggle against terrorism and separatism. The methodological basis of research contains the comparative and political approaches offering a new perspective of «Regional Integration» in Central Asia. The author concludes that the nuclear deal between Iran and the great powers, the lifting of sanctions and the reduction of America's political and economic pressures on Iran will lead to the favorable and mutually benefitial cooperation between Iran and Central Asian countries. The results of this collaboration can be the creation of an economic and trade alliance in the region.
\end{abstract}

Keywords: Terrorism, the Middle East, Sanction, Nuclear deal, Russia, USA, Central Asia, Iran, Economic cooperation, Transit of goods.

$\mathrm{B}$ ведение. На протяжении последних лет принятие Советом Безопасности $00 \mathrm{H}$ нескольких резолюций против ядерной программы Ирана и введение международных санкций привели к относительной изоляции Тегерана и резкому сокращению экономических, политических и культурных отношений Ирана с другими странами. С приходом к власти правительства Хасана Рухани внешняя политика Ирана, с целью конструктивного взаимодействия с миром, радикально изменилась [1].

В настоящее время, после ядерного соглашения, устранения угрозы войны с США и улучшения отношений с европейскими странами, внешняя политика Ирана сосредоточилась на расширении регионального сотрудничества и улучшении вза- имодействий с соседями. С геополитической точки зрения, Иран находится в непосредственной близости от двух основных регионов Персидского залива, Центральной Азии и Кавказа. Хотя международное внимание сосредоточено на деятельности Ирана в Персидском заливе и на Ближнем Востоке, Иран также является активным игроком в Центральной Азии и Афганистане. В последние месяцы усилия Ирана, имеющие своей целью начало новой эры в отношениях со своими южными соседями, из-за кризиса в Сирии, Йемене и регионального соперничества с Саудовской Аравией были не очень успешными, но в Центральной Азии ситуация иная. Центральная Азия, в том числе Казахстан, Узбекистан, Таджикистан, Туркменистан и 
Кыргызстан, с древних времен имеет тесные связи с Ираном. Эти исторические отношения обеспечили потенциально благотворное пространство для развития отношений Ирана со странами региона.

Иран сделал страны Центральной Азии после приобретения независимости приоритетом своей внешней политики. Внешняя политика Ирана в Центральной Азии, в отличие от внешней политики Ирана на Ближнем Востоке, всегда была прагматичной и не носила идеологический характер. У Ирана не было стимулов и возможностей для «выпуска» шиизма в суннитские общины региона и пропаганды его религиозной модели государства светским властям Центральной Азии. Характер отношений правительства Ирана со странами Центральной Азии определялся экономическими взаимодействиями, и какое-то время эти отношения Ирана со странами региона характеризовались значительным подъемом. Укрепление и развитие Организации экономического сотрудничества (ОЭС) происходило с той же целью [2, с. 133-134].

Крепкие и близкие отношения между Ираном и странами Центральной Азии способствовали укреплению национальной безопасности и экономическому развитию сторон. Отсутствие доступа к открытым водам у этих стран и использование геополитического положения Ирана для транзита товаров предоставило ему новые возможности. Тем не менее отношения Ирана с этими странами не достигли приемлемого уровня, и в последние годы вследствие конкуренции региональных и трансрегиональных игроков в отношении крупных энергоресурсов и массового рынка потребления в Центральной Азии арена присутствия Ирана в регионе была сужена [3, с. 45].

Проблемы во взаимоотношениях Ирана и стран Центральной Азии. Важнейшим препятствием для развития сотрудничества Ирана со странами Центральной Азии является влияние и вмешательство трансрегиональных держав. В то же время США прикладывали наибольшие усилия для подрыва присутствия Ирана в регионе. Они представили мнимую интервентскую и угрожающую картину Ирана, что оказало негативное влияние на процесс конвергенции между Ираном и правительствами стран региона. Несомненно, наиболее важным действием США следует считать выступления против использования иранской территории для транзита огромных энергоресурсов Центральной Азии на мировые рынки. В то время как коридор Север - Юг считается лучшим маршрутом транспортировки энергии из Центральной Азии, этот маршрут бойкотируется под влиянием политики США с целью игнорирования стратегического положения Ирана в регионе [4, с. 134-135]. Таким образом, ситуация в отношениях между Ираном и
Америкой была главным препятствием в развитии сотрудничества между Ираном и региональными правительствами. Кроме того, международные санкции против Ирана также повлияли на ограничение маневренной силы Тегерана в Центральной Азии.

Еще одним препятствием в развитии деятельности Ирана в Центральной Азии являются особые отношения между Ираном и Россией (в результате все большего отдаления Ирана от Запада), что привело к разработке политики и приоритетов Ирана с учетом рекомендаций и интересов России. Россия же, осуществляя евразийскую политику интеграции и для закрепления своей традиционной гегемонии, меньше всего желала, чтобы такие страны, как Иран, имели значительное присутствие в этом регионе. Москва ожидала, что Тегеран тоже уважительно отнесется к такой ситуации. Тем не менее ЕC, Китай, Турция и арабские страны являются чрезвычайно активными в этом регионе [5, с. 123-124].

Иран и Центральная Азия: перспективы сотрудничества после ядерного соглашения. Международные санкции «сковали» власти Ирана, но ядерное соглашение является началом пути присоединения Ирана к мировому сообществу. Со снятием санкций Иран превратится в важнейший маршрут для экономического обмена стран региона. Центральноазиатские лидеры приветствовали ядерную сделку с Ираном. Сотрудничество с Ираном позволит странам Центральной Азии иметь больше возможностей в своей внешней торговле. Министр иностранных дел Ирана Джавад Зариф в ходе своего визита в Казахстан заявил: «У Ирана нет ограничений для развития своих отношений со странами Центральной Азии и Кавказа». В заявлении президента Казахстана Нурсултана Назарбаева читаем: «Обе страны обладают высоким потенциалом для двустороннего сотрудничества и должны принять ряд мер для возрождения Шелкового Пути от Китая до Средиземного моря» [6]. Тем не менее высокий потенциал для двустороннего и многостороннего сотрудничества между сторонами имеется в перечисленных ниже важных областях.

Развитие транспортной системы и обмен товарами. Одним из наиболее важных ограничений, которые имеют страны Центральной Азии, является отсутствие выхода к морю, доступа к открытым водам. Эта проблема сократила торговые отношения этих стран с международными рынками и снизила их возможности для экономического роста.

В связи с этим Иран, из-за своего геополитического положения, привлек внимание Центральноазиатских государств в качестве одного из приоритетных вариантов сотрудничества. Основным преимуществом Ирана над всеми конкурентами является наличие наиболее дешевого и безопасно- 
го пути доступа к глобальным рынкам. Иран, имея более двух тысяч миль побережья на юге, обеспечивает доступ Центральной Азии к Ближнему Востоку, Индийскому субконтиненту и Дальнему Востоку. Торговля через Иран с запада - в Турцию и Европу и с юга - в страны Персидского залива, Восточной Африки и Юго-Восточной Азии приведет к экономическому подъему в Центральной Азии и увеличит переговорную силу республик Центральной Азии в торговых взаимодействиях с другими странами, такими как Китай. Напротив, геополитическое значение Ирана в регионе усилится [7]. Таким образом, развитие дорожной инфраструктуры и железнодорожных линий является важнейшим приоритетом в отношениях между Ираном и странами региона. Учитывая роль транспорта в конечной цене товара, очень важным в сегодняшней экономике является выбор соответствующего маршрута и упрощение транзита [8, с. 67]. Открытие железной дороги Иран - Туркменистан - Казахстан в конце 2014 года, в период после санкций против Ирана, оказало положительное влияние на торговые отношения в регионе.

С другой стороны, Центральная Азия потенциально является очень подходящим местом для привлечения инвестиций Ирана и подходящим рынком для продажи иранских товаров. Правительство Ирана пытается, сосредоточившись на областях, соответствующих объему инвестиций и уровню технологий иранских компаний, таких как строительство плотин, строительство гидроэлектростанций и дорог в регионе, увеличить свое экономическое присутствие в регионе [9, с. 150].

Транспортировка нефти и газа. В связи с колебаниями цен на нефть на мировых рынках страныэкспортеры при выборе путей экспорта нефти и газа должны учитывать экономические факторы. Транзитные пути Ирана являются прямым и безопасным маршрутом в открытое море, на южные и юго-восточные рынки Азии. Иран может стать наиболее быстрым и экономичным маршрутом из Центральной Азии на рынки потребления в Японии, Индии и Восточной Азии.

Иран обладает высококвалифицированными человеческими ресурсами, удобной транспортной системой, портами, нефтеперерабатывающими заводами, то есть имеет ценные логистические преимущества для экспортеров нефти и газа $[10$, с. $42-$ 45]. Ожидается, что с ослаблением напряженности между Ираном и странами Запада после ядерного соглашения, сложившегося в результате распространения терроризма на Ближнем Востоке, США будут иметь более конструктивный подход в соответствии с экономическими зонами в отношении сотрудничества Ирана со странами Центральной Азии. С другой стороны, российские лидеры после ядерного соглашения и ослабления напряженности между Ираном и Западом стремятся поднять на более высокий уровень двустороннее и региональное сотрудничество с Ираном, доказательство этого военное сотрудничество между Москвой и Тегераном в Сирии и Ираке, и есть вероятность того, что в отличие от прошлого опыта Россия поддержит присутствие Ирана в Центральной Азии для укрепления своих с ним отношений [11]. Иран по причине экономических проблем не может быть серьезным конкурентом для России, но может стать для нее полезным партнером в противостоянии однобокой политики США в регионе. В области производства и экспорта нефти и газа в регионе Россия и Иран конкурируют друг с другом, и эта конкуренция может превратиться в сотрудничество, поскольку Иран и Россия имеют общую заинтересованность в увеличении и стабилизации мировых цен на энергоносители. Также существуют возможности для сотрудничества между Россией и Ираном по маршрутам транспортировки энергии. Политика России для доступа на потребительские рынки в основном в Индии и Юго-Восточной Азии осуществляется с использованием географического положения Ирана.

ВЫВоды. Глобализация мировой экономики формирует новые конкурентные условия, в них выживут только мощные и эффективные экономические единицы. Таким образом, правительства обращаются к регионализму и созданию региональных организаций, с тем чтобы с помощью друг друга защитить свою экономику от мировых проблем и достичь экономического роста посредством использования сравнительных преимуществ в регионе. На самом деле существует положительная связь между региональной интеграцией и экономическим развитием стран. Хотя в отношениях между Ираном и Центральной Азией были взлеты и падения, эти страны заинтересованы в укреплении отношений и использовании экономических возможностей и географического положения Ирана. С приходом к власти правительства Рухани в Иране, планом разрядки напряженности и конструктивного взаимодействия с международной системой, ядерным соглашением и снятием санкций против Ирана ослабло негативное влияние США на отношения Ирана с Центральной Азией, а также были созданы идеальные условия для прорыва в отношениях стран Центральной Азии с Ираном. В связи с увеличением роли Ирана в решении конфликтов на Ближнем Востоке и борьбе с терроризмом в Сирии, Ираке и Афганистане США нуждаются, по крайней мере в среднесрочной перспективе, в тесном партнерстве с Ираном, что дает возможность Ирану углубить отношения со странами Центральной Азии.

Конечно, в последние годы правительство России не имело серьезного сотрудничества, 
особенно в экономической сфере, с Ираном в Центральной Азии. Однако после событий на Украине, ядерного соглашения Ирана и распространения кризиса на Ближнем Востоке активизация Ирана в Центральной Азии, по сравнению с влиянием других конкурентов, таких как США и Турция, России лишь на пользу. Обе страны имеют общие интересы в создании стабильности и безопасности, экономическом развитии и борьбе с исламским радикализмом в Центральной Азии и на Кавказе. Результатом этого взаимодействия, с расширением основных общих интересов, может стать создание большого торгово-экономического союза в регионе.
Таким образом, возвращение Ирана в мировое сообщество (путь, первым шагом к которому является ядерное соглашение) повлияет на рост экономики в Центральной Азии. Иран благодаря множеству общих черт с Центральноазиатским регионом, таких как общие водные и сухопутные границы, культурные и исторические параллели, сходные цели в борьбе с терроризмом и возможность присоединения Центральной Азии к свободным водам и Индийскому океану, может, взяв за основу экономический подход, достичь стратегического взаимовыгодного сотрудничества со странами этого региона. Общие потребности и интересы сделали необходимым такое тесное сотрудничество и без влияния мировых держав.

\section{Библиография:}

1. Руми Ф. Внешняя политика и стратегические приоритеты президента Ирана Хасана Рохани. - [электронный реcypc]. - URL: http://www.imomi.unn.ru/files/2014/06/.pdf.

2. Уостнидж Э. Внешняя культурная политика Ирана в Центральной Азии: демонстрация политического прагматизма // Центральная Азия и Кавказ. - 2014. - Т. - 17. № 4. - С. 131-144

3. Кулаий Э. Новая Большая игра в Центральной Азии // Тегеран: офис политических и международных исследований. - 2006. (В персидском)

4. Yuldasheva G. Geopolitics of Central Asia in the context of the Iranian factor // Caucasian Review of International Affairs. 2008. Vol. 2. - № 3. - P. 133-145.

5. Корнилов А.А., Руми Ф. Российско-иранские отношения в период президента М. Ахмадинежада // Научные ведомости Белгородского государственного университета. Серия: История. Политология. 2015. - № 7 (204). - Вып. 34. - С. 120 -124.

6. Putz C. Why is Central Asia excited about the Iran Deal? .- [электронный ресурс]. URL: http://thediplomat.com/2015/04/ why-is-central-asia-excited-about-the-iran-deal/

7. Ovozi Q. Does Nuclear Deal Presage A New Era For Iran-Central Asia Relations? April 06, 2015. - [электронный ресурс]. URL: http://www.rferl.org/content/qishloq-ovozi-iran-central-asia/26941315.html.

8. Кулаий Э., Эбрахими А. Объяснение геополитических отношений Исламской Республики Иран и Республики Казахстан // Геополитика. - 2013. - № 2. - С. 49-81.(В персидском)

9. Атаий Ф., Шибани А. Сферы сотрудничества и соперничества Ирана и России в Центральной Азии в рамках геополитики // журнал Центральной Евразии . - 2012. - № 8. - С. 131-151. (В персидском)

10. Sanaei M., Atrisangari F. Iran-Russia Foreign Policy in Central Asia // Discourse: An Iranian Quarterly. - Vol. 11. - № 1-2. Fall 2013 .- Winter 2014. P. 25-48.

11. Weitz R. Iran's empowerment in Central Asia and the South Caucasus // The Central Asia-CaucasusAnalyst. - 190ct.2015. [электронныйресурc]. URL: http://www.cacianalyst.org/publications/analytical-articles/item/13293-iransempowerment-in-central-asia-and-the-south-Caucasus.html

\section{References (transliterated):}

1. Rumi F. Vneshnyaya politika i strategicheskie prioritety prezidenta Irana Khasana Rokhani. - [elektronnyi resurs]. - URL: http://www.imomi.unn.ru/files/2014/06/.pdf.

2. Uostnidzh E. Vneshnyaya kul'turnaya politika Irana v Tsentral'noi Azii: demonstratsiya politicheskogo pragmatizma // Tsentral'naya Aziya i Kavkaz. - 2014. - T. - 17. № 4. - S. 131-144

3. Kulaii E. Novaya Bol'shaya igra v Tsentral'noi Azii // Tegeran: ofis politicheskikh i mezhdunarodnykh issledovanii. - 2006. (V persidskom)

4. Yuldasheva G. Geopolitics of Central Asia in the context of the Iranian factor // Caucasian Review of International Affairs. 2008. Vol. 2. - № 3. - P. 133-145.

5. Kornilov A.A., Rumi F. Rossiisko-iranskie otnosheniya v period prezidenta M. Akhmadinezhada // Nauchnye vedomosti Belgorodskogo gosudarstvennogo universiteta. Seriya: Istoriya. Politologiya. 2015. - № 7 (204). - Vyp. 34. - S. 120 -124.

6. Putz C. Why is Central Asia excited about the Iran Deal? . - [elektronnyi resurs]. URL: http://thediplomat.com/2015/04/ why-is-central-asia-excited-about-the-iran-deal/

7. Ovozi Q. Does Nuclear Deal Presage A New Era For Iran-Central Asia Relations? April 06, 2015. - [elektronnyi resurs]. URL: http://www.rferl.org/content/qishloq-ovozi-iran-central-asia/26941315.html.

8. Kulaii E., Ebrakhimi A. Ob"yasnenie geopoliticheskikh otnoshenii Islamskoi Respubliki Iran i Respubliki Kazakhstan // Geopolitika. - 2013. - № 2. - S. 49-81.(V persidskom)

9. Ataii F., Shibani A. Sfery sotrudnichestva i sopernichestva Irana i Rossii v Tsentral'noi Azii v ramkakh geopolitiki // zhurnal Tsentral'noi Evrazii . - 2012. - № 8. - C. 131-151. (V persidskom)

10. Sanaei M., Atrisangari F. Iran-Russia Foreign Policy in Central Asia // Discourse: An Iranian Quarterly. - Vol. 11. - № 1-2. Fall 2013 .- Winter 2014. P. 25-48.

11. Weitz R. Iran's empowerment in Central Asia and the South Caucasus // The Central Asia-CaucasusAnalyst. - 190 ct.2015. - [elektronnyiresurs]. URL: http://www.cacianalyst.org/publications/analytical-articles/item/13293-iransempowerment-in-central-asia-and-the-south-Caucasus.html 